\title{
MEMÓRIAS DO CATIVEIRO E DO JONGO NO VALE HISTÓRICO DO RIO PARAÍBA DO SUL - SÃO PAULO ${ }^{1 / /}$ Diego da Costa Vitorino ${ }^{2}$ e Dulce
}

\section{Consuelo Andreatta Whitaker ${ }^{3}$}

Palavras-Chave
manifestações culturais / jongo / bananal / memória

1111111111111111111111111111111111111

\section{Sumário}

1 Introdução

2 As memórias do cativeiro

3 A família negra e a manutenção da memória social

4 As memórias do Jongo em Bananal

5 Referências

\section{Resumo}

Este trabalho objetiva visibilizar o Jongo, expressão da cultura imaterial negra, a partir de pesquisa etnográfica realizada em Bananal-SP, cidade no Vale Histórico do Rio Paraíba do Sul, atualmente com cerca de 11 mil habitantes. A descrição sincrônica da vida cotidiana desta pequena cidade, construída a partir da observação etnográfica e do caderno de campo, possibilitou aos pesquisadores resgatar memórias do cativeiro e histórias de vida de algumas famílias negras, que guardam relatos importantes sobre nosso passado colonial. A sincronia do relato etnográfico foi questionada pela diacronia dos fatos históricos referentes ao povoamento da região, transformado pelo desenvolvimento das lavouras de café no Vale do Paraíba paulista, no início do Novecentos. Este trabalho é fruto da tese de doutorado "Um Divórcio entre Escola e Comunidade? Bananal-SP, um 'laboratório a céu aberto' no Vale Histórico do Rio Paraíba do Sul". Para além dos muros da escola local, havia memórias, músicas e danças característicos das populaç̃oes negras trazidas pela diáspora africana, tal como a antifonia do canto no Jongo, que revela sua herança cultural. Argumentamos que foram as altas taxas de famílias negras, historiograficamente confirmadas, que possibilitaram a manutenção da memória individual e coletiva dos africanos e afro-brasileiros na localidade. Essas memórias subalternas desvelam uma visão de mundo, além de manifestações culturais negras que resistiram às passagens dos séculos XIX, XX até o início do XXI. A cosmogonia, presente até hoje na cidade, dá particularidade histórica à identidade da população local e demonstra a diversidade cultural no estado de São Paulo.

10 presente artigo é uma versão revisada do trabalho apresentado no V ENADIR - Encontro Nacional de Antropologia do Direito (2017). GT.8 - Festejos, rituais e a salvaguarda dos direitos culturais. 2 Doutor em Educação Escolar e Professor-pesquisador no Curso de Especialização em Coordenação Pedagógica vinculado à Fundação da UFSCar: divitorino@yahoo.com.br

3 Doutora em Sociologia e professora em cursos de Pós-Graduação da UNESP/FCL, Araraquara, e da UNIARA - Centro Universitário de Araraquara: silonofre@uol.com.br 


\section{MEMORIES OF CAPTIVITY AND JONGO IN THE PARAÍBA DO SUL RIVER HISTORICAL VALLEY - SÃO PAULO // Diego da Costa Vitorino and Dulce Consuelo Andreatta Whitaker}

\author{
Keywords \\ cultural manifestations / jongo / bananal / memory
}

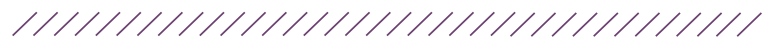

\begin{abstract}
This work aims to give visibility to Jongo, an expression of black immaterial culture, by means of an ethnographic research carried out in Bananal-SP, a city located in the Paraíba do Sul River Historical Valley, nowadays comprised of around 11 thousand inhabitants. The synchronic description of the daily life of this small city, built from the ethnographic observation and field notes, enabled the researchers to retrieve memories of captivity and life histories of black families, who still hold important accounts for understanding our colonial past. The synchronicity of the ethnographic account was questioned by the diachronic nature of the historical facts concerning the process of settlement of the region, profoundly changed by the development of coffee plantations in the Paraíba Valley, in the state of São Paulo, during the early nineteenth century. This work is the result of a doctoral thesis entitled "A Divorce between School and Community? Bananal-SP, an 'open-air laboratory' in the Historic Valley of the Paraíba do Sul River". Beyond the walls of the local school, there were memories, songs and dances that are characteristic of the black populations brought by the African diaspora, such as the chorus in Jongo songs, which reveal their cultural heritage. This thesis arguments that the high rates of black families, historiographically confirmed, enabled the maintenance of the individual and collective memory of Africans and AfroBrazilians in the locality. These subaltern memories unveil a worldview, as well as black cultural manifestations that resisted the passages of the nineteenth and twentieth centuries, up until the beginning of the twenty-first. The cosmogony present to this day in the city gives historical particularity to the identity of the local population, as well as demonstrates the cultural diversity in the State of São Paulo.
\end{abstract}




\section{Introdução}

Esta pesquisa, feita através de observação direta e contato próximo com os sujeitos participantes, foi uma tentativa de captar a força e a persistência da cultura afrobrasileira que permanece na memória como marca de identidade. Para isso, nós desenvolvemos uma etnografia que teve como lócus a educação na escola e na comunidade de uma pequena cidade chamada Bananal, localizada no estado de São Paulo4

Nesse sentido, não nos interessa aqui evocar a contribuição dos negros à cultura hegemônica, trazendo para a discussão, por exemplo, os grandes intelectuais negros que, apesar de importantes, sem dúvida, ocidentalizaram-se. Alguns chegaram a ser literalmente branqueados, como Machado de Assis, em certas reproduções fotográficas.

Também não nos interessou a contribuição afroamericana e africana que necessitou do sincretismo para sobreviver na cultura hegemônica, tal como o caso da religião e da música popular. São aspectos importantes, mas bastante enfatizados - não só no senso comum, como também em trabalhos científicos - e se apresentam como as "contribuições" afrobrasileiras que "desaparecem" no turbilhão histórico cultural. Procuramos a resistência e, nesse contexto, Bananal, situada no Vale Histórico do Rio Paraíba do Sul, apresentou-se como um cenário possível.

Uma hipótese testada nesta pesquisa está expressa no título da tese de doutoramento: "Um Divórcio entre a Escola e a Comunidade? Bananal/SP um "laboratório" a céu aberto no Vale Histórico do Rio Paraíba do Sul" desenvolvida por Diego Vitorino, primeiro autor deste artigo, sob a orientação de Dulce Whitaker, segunda autora (Vitorino, 2014),. A hipótese acabou se tornando uma questão de tese dada a noção do divórcio entre a instituição escolar e a comunidade.

Poderíamos afirmar que existiria na escola de Bananal, como na maioria dos sistemas de ensino, a ideia de que ela deva romper com os saberes populares? Será que a escola também acreditaria na ideia de que a construção do conhecimento socialmente valorizado se encontra apenas nos livros e na cultura dita "erudita", construindo-se através da leitura dos clássicos? Entender a relação escola e comunidade foi fundamental para a elaboração do estudo realizado.

Romper com a cultura popular é o que propõem alguns pedagogos brasileiros de renome, entendendo que a escola deveria fornecer aos filhos das camadas de trabalhadores todos os conteúdos que estão ao alcance das classes abastadas, o que facilitaria (em suas concepções) a integração dessas camadas na sociedade de classes.

Diante de tais dilemas há outras correntes teóricas, sobretudo a pedagogia revolucionária de Paulo Freire, que colocaram em questão o processo de alfabetização dos grupos subalternos na América Latina e em alguns países Africanos e, ainda hoje, apresentam-se como pedagogias capazes de desvelar contradições apresentadas pela dialética opressor-oprimido.

O que se observa é que, inserida em uma realidade riquíssima, tanto do ponto de vista da natureza preservada, quanto de memórias subalternas, como as dos negros, a educação escolar de Bananal (formal e pública) se apresenta distante, burocratizada e alheia aos elementos da comunidade, os quais poderiam formar um currículo atraente e eficiente no ensino-aprendizagem das crianças.

As práticas tradicionais presentes na comunidade são, sistematicamente, ignoradas pela escola no processo de ensino-aprendizagem de seus estudantes, além de algumas vezes serem consideradas crendices, mitos, folclore ou saberes inexpressivos para a escolarização. As memórias sociais dos negros e dos povos da floresta (como os da Serra da Bocaina) são muitas vezes descartadas pela escola de ensino fundamental em Bananal.

\footnotetext{
4 Segundo dados do Censo Populacional de IBGE (2010), a população de Bananal era de 10.223 habitantes na época. Está situada como cidade da Região Administrativa de São José dos Campos, estado de São Paulo. Disponível em: http://cidades. ibge.gov.br/xtras/perfil.php?lang=\&codmun=350490\&search=sao-paulo|bananal (Acesso em 03.08.17)
}

\section{As memórias do cativeiro}

Inicialmente, para entendermos como essas memórias do cativeiro se constituíram, precisamos compreender os desdobramentos decorrentes das 
rotas do tráfico negreiro Sul Atlânticas na formação demográfica e cultural dessa parte do estado de São Paulo. Apesar dos historiadores admitirem que os dados sobre o tráfico de africanos para o Brasil, entre os séculos XVI e XVII, são pouco consistentes, há que reconhecer a relação profunda entre a África Central Ocidental (e quem sabe a África Central Oriental) e o nosso país (Alencastro, 2000; Slenes, 2007; Knight, 2011; Vansina, 2011).

Como se pode constatar no início da obra de Alencastro (2000), a formação do Brasil ocorreu fora do território nacional, mais precisamente no eixo Sul Atlântico:

Desde o final do século XVI, surge um espaço aterritorial, um arquipélago lusófono composto dos enclaves da América portuguesa e das feitorias de Angola. É daí que emerge o Brasil no século XVIII. Não se trata, ao longo dos capítulos, de estudar de forma comparativa as colônias portuguesas no Atlântico. O que se quer, ao contrário, é mostrar como essas duas partes unidas pelo oceano se completam num só sistema de exploração colonial cuja singularidade ainda marca profundamente 0 Brasil contemporâneo. (Alencastro; 2000, p. 9) (Grifos nossos)

Com isso, queremos estabelecer as conexões mais específicas entre a África central ocidental e a formação de uma cosmogonia negra no Brasil. As historiografias, aqui referenciadas, são o alicerce para a compreensão de histórias que se formaram a partir da tradição oral dos grupos africanos traficados pelas rotas oceânicas em direção à América.

Vansina (2011) afirma que os brasileiros passaram a dominar totalmente o comércio de escravos em Angola de 1648 a 1730. Além do trânsito de pessoas e ideias da África para o Novo Mundo, muitas plantas saíam da América para a África, confirma o autor: milho, amendoim, mandioca, feijão e tabaco. Estabelecia-se, portanto, uma lucrativa rota comercial e, sobretudo, criava-se entre o Brasil e a África centro-ocidental uma dependência econômica e social sem igual.

Segundo o autor, desde o fim do século XVII a coroa portuguesa já não possuía o controle do comércio de escravos, que ficou na mão de quimbares, ovimbares (melhor identificados como afro-portugueses), além do domínio dos brasileiros em Luanda e Benguela.

Com o declínio dos Estados africanos, no século XVIII, houve o fortalecimento das redes comerciais, o que possibilitou o tráfico de mais de 6 milhões de africanos para outros continentes somente nesse século, dos quais 1,8 milhão vieram para o Brasil, ou seja, 31,3\% (Vansina, 2011).

O mesmo autor considera que a mortalidade atingia de 10 a 15\% dos que embarcavam rumo ao Novo Mundo e a oscilação desse percentual estava atrelada ao grau de amontoamento dos africanos transportados. Com base nesses dados sobre o tráfico, o autor é enfático ao afirmar que Angola dependia economicamente do Brasil e que, por volta de $1800,88 \%$ dos rendimentos dessa nação africana provinham do tráfico de pessoas para o território brasileiro.

Já Knight (2011), um africanista que estudou a diáspora, explica-nos que, escravos ou homens livres, os africanos e afro-americanos contribuíram para domesticar grande parte de toda a extensão selvagem do continente americano, chegando a afirmar: "Qualquer que tenha sido o número de africanos em tal ou qual país, a África imprimiu, na América, a sua marca profunda e indelével" (Knight; 2011, p. 877, grifos nossos).

São estas as marcas que sobrevivem em Bananal-SP? Para Knight (2011), a diáspora africana foi muito maior na América do que na Europa e na Ásia. Na América, no início do século XIX, a população de afro-americanos chegava a 8,5 milhões entre homens livres e escravos. Desses, dois milhões encontravam-se nos EUA e outros dois milhões nas Antilhas.

Segundo o mesmo autor, o Brasil abrigava 2,5 miIhões de afro-americanos no século XIX e na América espanhola continental o montante chegava a 1,3 milhão. Para Knight (2011) os africanos influenciaram fortemente as regiões rurais de grande latifúndio e toda a margem atlântica da América, desenvolvendo os mais variados tipos de produção e desempenharam todos os papéis sociais:

Eles foram pioneiros e conquistadores, piratas e bucaneiros, gaúchos, llaneros, bandeirantes, pro- 
prietários de escravos, negociantes, domésticos e escravos. Eles melhor se distinguiram em certos ofícios comparativamente a outros, mas, no entanto, $o$ acesso às mais elevadas posições sociais thes fora interditado pela lei. Após o século XVII, entretanto, os africanos eram os únicos escravos legais nas duas Américas e as populações africanas no seio das sociedades americanas estariam predestinadas a carregar, durante longo período, os estigmas desta condição. Antes da abolição definitiva da escravatura no Brasil, em 1888, a maioria dos africanos das Américas era escrava e eram eles quem cumpriam a maior parte dos trabalhos manuais e dos serviços que exigiam um esforço físico, frequentemente estafante, sem os quais as colônias, possessões e nações não teriam sido capazes de alcançar a prosperidade econômica. (Knight; 2011, p. 877)

Como já afirmamos, os dados da escravidão que abasteceram a América são bastante controversos, entretanto, Knight (2011) afirma que P. D. Curtin é quem melhor oferece uma imagem global desse fluxo, chegando a uma cifra de 10 milhões de escravizados. Retificando este total, há a pesquisa de E. D. Genovese, entre outros pesquisadores, que aumentou essa estimativa para 2 a 3\%, ou seja, cerca de 12 a 13 milhões.

Independente do total, o Brasil foi o maior importador, chegando a ter $38 \%$ dos africanos escravizados vindos para a América. Porém, antes da introdução de parte desses africanos escravizados para o trabaIho na lavoura de café, seja na cidade de Bananal ou em toda a parte leste do estado de São Paulo, a demografia na região era bastante diferente.

Bananal e o Vale Histórico do Rio Paraíba do Sul (Silveiras, Areias, Arapeí, São José do Barreiro) foram as primeiras regiões a produzir café no estado de São Paulo, segundo Motta (1999). No fim do século XVIII eram poucas as propriedades que produziam café na região e a agricultura desenvolvida era de subsistência: produzia-se milho, mandioca, galinhas e porcos. Antes, no século XVI, essa região era ocupada por índios Puris, de língua Jê (Motta, 1999; Graça, 2006).

Foi nas lavouras de café que muitos agricultores, descendentes de habitantes pobres, povoaram o Vale do Paraíba paulista no século XVII, enriqueceram entre as décadas de 1800 a 1830 e formaram algumas das principais fortunas da época, chegando, alguns, a se tornar barões no período Imperial do Brasil, cujos títulos foram outorgados por Dom Pedro II.

Através da análise dos dados sobre a vida na senzala Motta (1999) elaborou a noção de corpos escravos. Segundo ele, e a partir da lista nominativa de 1801, a cidade de Bananal não contava com grandes planteis no início do século XIX. Para ele, a evolução dos padrões de propriedade de cativos seguiu os efeitos da maior produtividade do café, do início da segunda metade do século XIX (MOTTA, 1999, p. 109).

Esses dados considerados pelo autor colocam em relação a economia e a demografia da cidade no período. De 1830 a 1850, Motta (1999) afirma ser o apogeu da produtividade do café e do poder econômico dos cafeicultores de Bananal. Esses dados nos levaram a um argumento importante: a grande presença de famílias negras em Bananal (maior que em outras cidades da região, como Lorena) foi o que possibilitou que as memórias do cativeiro e do Jongo ainda permanecessem entre seus habitantes.

$\mathrm{Na}$ contramão da história oficial, que ilustra a vida da elite cafeeira no século XIX, a bibliografia que utilizamos tem como objetivo situar a vida daqueles que foram excluídos da educação formal, de melhores condições de vida e dos salões de baile imperiais. As memórias do cativeiro e do Jongo trazem à tona a cosmogonia dos negros da diáspora, a partir do prisma da musicalidade e dos saberes, o que nos remete sempre ao contexto da senzala no século XIX.

A senzala e o terreiro de café foram os locais onde a visão de mundo desses corpos escravizados foi transmitida através da oralidade 5 . Por isso, ao invés de analisarmos a vida nos salões nobres construídos para as elites do Império, propomos o inverso: analisar a vida da comunidade pobre e negra, ontem e hoje.

5 As religiões afrobrasileiras não foram analisadas na tese de Vitorino (2014). O terreiro que se analisou foi o quintal da propriedade rural, cenário de festejos e da cultura popular, e não o Terreiro de Umbanda ou de Candomblé. 


\section{A família negra e a manutenção da memória social:}

Para conhecermos mais as memórias do cativeiro, recorremos à história oral, relatada pela história de vida de alguns interlocutores, descendentes de famílias negras de Bananal, cujos saberes e tradições foram aprendidos com as gerações mais velhas e guardados na memória.

Uma interlocutora nascida em Bananal, com 78 anos no momento da pesquisa, narrou-nos as histórias de sua avó materna, nascida sob a lei do Ventre Livre e falecida aos 105 anos, em local próximo à fazenda escravocrata onde seus familiares tinham sido escravos. Ao trazer à tona a memória de sua avó, que vivera na fazenda Coqueiros, dona Tereza resgatou as memórias do cativeiro, a visão de mundo dos africanos e afrobrasileiros, a cosmogonia e as condições de vida que esses escravizados enfrentavam nas lavouras de café.

As memórias do cativeiro, ainda hoje, se mantêm vivas nas histórias dos sujeitos da comunidade e podem ser acessadas pela história oral. Tais memórias só são possíveis de se resgatar pelo registro de narrativas das famílias negras, uma vez que a literatura sobre o período colonial direcionou seus esforços, na maioria das vezes, para a vida da classe dominante da época e não para as vidas dos corpos escravos.

Recorremos à história de vida da avó materna de dona Tereza e a alguns relatos de dona Mariinha Basílio, também moradora de Bananal, sobre Jorge Basílio, seu avô paterno. Para a análise das memórias do cativeiro, da senzala e do terreiro no Brasil colonial, agregamos aos dados historiográficos, acima expostos, essas duas narrativas sobre a escravidão, coletadas em 17 de março e 14 de maio de 2012, respectivamente.

Os avós maternos de dona Tereza se chamavam Camila Maria José e Militão Miguel de Oliveira, sua bisavó foi Pracide Maria José e seu bisavô era Antônio. Numa passagem, muito significativa em termos de sentidos e percepções da memória do cativeiro, dona Tereza conta como foi o final da vida de sua bisavó.

Inicialmente soubemos desta história pela atual proprietária da fazenda Coqueiros, Maria Elizabeth Brum. A partir dessas informações, chegamos à Maria
Tereza de Paula (dona Tereza), que narrou as memórias da avó sobre a sua bisavó. Dona Tereza conta-nos como foi o final da vida da bisavó:

Essa aí que ela contava [a história] era da mãe dela. É do tempo da minha bisavó, que trabalhava lá [fazenda Coqueiros]. Ela foi cozinheira lá muito tempo. Então, dizia que todo mundo gostava dela, tanto que eles não queriam outra cozinheira. Daí ela engravidou e ganhou o neném à noite. No outro dia, ela não foi trabalhar. Mandou então avisar que ela não ia trabalhar. Mas a patroa disse: "- Ah, não. Tem que vir! Porque você tem que vir fazer a comida". Mas ela não estava aguentando. Fizeram ela ir e ela foi. Deixou o neném e foi. Chegando lá, começou a se sentir mal e se desmontou lá na cozinha. Punha ela de pé e ela caía. Aí os fazendeiros disseram assim: "- Se você não está aguentando! Quer morrer? Então morre!". Aí os patrões dela começaram a bater nela e naquele tempo não podia falar nada. Como ela estava fraquinha acabou morrendo. Depois enterrou ela lá. Não tem uma escada que desce assim da cozinha? [explicou $d$. Tereza] Dizem que enterrou ela por ali mesmo. Diz que era para ela não esquecer que o lugar dela era na cozinha. Aí as outras "irmãs", que tivesse amamentando e tivesse criança, acabaram de criar o neném. Que era um menino. Esse menino também não foi escravo. Porque logo acabou a escravidão. Minha avó ouvia essa história porque ela era filha da que morreu. (grifos nossos)

Dona Tereza revela situações do cotidiano, de vida e morte de familiares e outras pessoas escravizadas. No foco dessa passagem temos sua bisavó, Pracide, que, segundo o relato de Camila Maria José, teve seu corpo enterrado na cozinha da fazenda Coqueiros como forma dos senhores demonstrarem aos escravizados a relação de hierarquia entre eles e os barões.

A irmandade relatada entre os escravizados surge como uma força coletiva, a partir dos laços de uma família extensa composta pelos integrantes da senzala, a fim de manter a unidade do grupo frente aos mandos e desmandos dos senhores. Estes, através de castigos e humilhações, procuravam destruir a solidariedade do grupo com uma arma simbólica bastante eficaz: o medo. No cenário arquitetônico da 
memória é constante a referência à senzala, ao terreiro e à casa-grande, de modo que estes três espaços têm correspondência na hierarquia da estrutura social. A casa-grande era o local de prestígio social (o espaço de quem manda) e a senzala o local da subserviência, de quem deveria obedecer, mas também o da resistência. Há, portanto, entre casa-grande e senzala uma relação dialética.

$\mathrm{Na}$ casa-grande, os descendentes dos antigos agricultores corriam para transformar seu status social, importando da Europa mercadorias e costumes, que nunca fizeram parte da realidade brasileira. Estes costumes e hábitos acabavam tornando esses sujeitos cheios de protocolos. O objetivo desse sincretismo era se afastar dos hábitos simples dos trabalhadores rurais, comuns na região, através da aquisição de um verniz ou polimento capaz de transformar agricultores em barões da corte do Império.

Na senzala, a resistência dos sujeitos escravizados transmitiu, pela oralidade, tradições e valores ancestrais. Nesse espaço compartilhado por africanos e afrobrasileiros surgiram costumes e modos de vida que se arraigaram em nossa cultura popular.

O terreiro de café da propriedade agrícola não era apenas local de trabalho. Nele os corpos escravizados manifestavam suas crenças e cultura, por isso era também espaço de construção de identidades e memórias desse grupo. Era nos terreiros (no quintal do latifúndio) que os jongueiros entoavam seus pontos, seguidos do coro e do som do tambor que se deslocava entre a senzala e a casa-grande.

Nesse contexto, as diferenças socioculturais entre os grupos, passavam a ser hierarquizadas com base em crenças evolucionistas que justificavam a estrutura social forjada pela elite agrária da localidade.

Outra questão de grande importância foi a existência de muitas famílias escravas, assim como salientam as historiografias de Motta (1999) e Slenes (2007). Encontramos dados qualitativos sobre essa questão em relatos da família de Mariinha Basílio, como veremos a seguir.

Segundo dona Maria Aparecida Souza da Costa - conhecida em Bananal como Mariinha Basílio - com
65 anos na época da entrevista e moradora do bairro do Educandário desde muito jovem, seu avô era um grande rezador. Chegamos a ela através de uma amiga de Bananal, que levou a sério a nossa procura na comunidade por pessoas que guardassem as memórias do cativeiro. O pai e avô paterno de Mariinha Basílio foram rezadores:

O meu pai e o meu avô, pai e filho, o João Jorge Basílio e o Jorge Basílio, eram rezadores. Meu pai rezava muito pra defunto, terços de São João [...] E o meu avô era mais de rezar por ações para curar [...] Era um benzedor antigo que ele benzia uma dor de cabeça, sumia a sua dor de cabeça na hora; se tinha uma mulher sangrando, ele rezava e o sangramento dela acabava; isso eu cheguei a ver. Se tinha uma criança vomitando, ele chegava, rezava e, no dia seguinte, você podia ver que a criança não tinha nada; e ainda tinha essa reza pesada dele que ele quis ensinar, mas meu pai não deixou ele ensinar.

Nessa passagem, a interlocutora salienta a eficácia das rezas e sugere que seu avô era bastante requisitado entre os membros da comunidade a fim de acabar com o sofrimento das pessoas. Percebe-se, portanto, que ao contrário do que ocorre com os sacerdotes (cuja eficácia provém da assimilação da doutrina e se vinculam com a instituição religiosa), a eficácia simbólica dos atos dos benzedores decorre da afirmação e aceitação de seu trabalho frente ao grupo para o qual está a serviço.

Mariinha recorda que seus avós paternos eram negros. Insistimos, em certo momento da entrevista, para que dona Mariinha falasse sobre a reza e o que lhe era proibido saber. Reza essa que, de fato, era uma das brigas entre Jorge e João Jorge Basílio - respectivamente avô e pai da interlocutora. Ela falou da relação entre avô e pai: "meu pai era muito enérgico e, meu avô, ele tinha costume de passar no quintal e roubar galinha". Em outro momento, ela falou sobre a reza proibida:

É a reza que era para espantar o inimigo. Ele chamava os da polícia de inimigos. Poderiam eles ir procurar ele que não encontravam. E por duas vezes ele mostrou: - Aqui fia! [o avô dizia a Mariinha:] ele conversava com a gente e dizia: - hohoho fia, é aqui que eu fiquei. Os homens passou correndo e 
me deixou aqui igual a um toco! E o pai confirmava, e é verdade! Por isso que o pai não gostava muito dele junto com a gente; pai tinha medo.

O pai de Mariinha, além do medo, como ela mesma diz, era muito católico e frequentava a Folia de Reis como instrumentista. Certamente a reza para espantar o inimigo era mal interpretada pelo pai. Insistimos na conversa, novamente, devido à curiosidade de saber mais sobre a reza proibida e ela falou mais sobre o avô. Perguntamos: "- Mas o que tem o inimigo? Quem era?", sem saber o que ela iria me responder. Apesar de certo embaraço e de ter sido interrompida por uma visita que chegava em sua casa, Mariinha disse, mesmo não sabendo por onde ou como começar:

Estavam atrás dele, por duas vezes isso aconteceu. Ele matou um homem numa briga e a polícia foi pra pegar ele. [...] Ele disse que viu a polícia de longe, lá na Serra do Turvo. Inclusive na terra que hoje é minha. [...] Os homens que ele via de longe (no caminho do Cesário) [...]é o caminho onde eu passo e onde o meu avô escondeu e de onde ele viu os homens chegando. Porque é assim: subindo aqui se vai lá pro lado do Alípio e o meu sítio é o último virado lá do outro lado. Quando se sobe, de lá a agente vê todo mundo que tá subindo. Dizia ele que naquele caminho é que as polícias estavam subindo. [...] ele sabia onde eles estavam indo. Ele encostou na beira do caminho e rezou. Fez a oração e as polícias passaram e não viram ele. Fizeram a volta e saíram do outro lado onde meu pai morava. Perguntaram para o meu pai e ele falou: "- Meu pai tá em casa. Depois ele [o avô] chegou rindo: “- Enganei os homens! Hum, hum, enganei os homens. Os homens foram lá pra me pegar. Eu rezei aquela oração e fiquei quietinho". Ele sempre falava: "-Eu preciso ensinar essa oração". Mas meu pai falava: - Se o Sr. começar essa oração eu vou brigar com o senhor. Ele nunca ensinou, minha mãe tinha loucura pra aprender essa oração dele.

Depois de insistir tanto, mudamos de assunto. Perguntamos à Mariinha se seu avô benzia muitas pessoas:

Ele curava e curou muito meu filho. Eu posso te garantir que ele curou muita gente. Era uma pessoa muito boa, tirando as bebidas dele. O resto, ele era maravilhoso, muito bom, muito prestativo, gostava muito de fazer o bem para os outros. Mas quando ele bebia umas cachaças ele ia para o quintal do vizinho comer umas galinhas [Risos].

Em uma certa altura da entrevista perguntamos sobre as histórias do tempo da escravidão e ela contou que seu avô "pegou muito" a escravidão e morreu aos 90 anos:

O Vô contava que meu tio nasceu na semana da libertação, meu tio Joaquim. A gente ainda brincava com ele: Eh tio Joaquim. O Sr. se livrou dos amarrados. Se livrou do sapatão de ferro. E o vovô contava pra gente que ele era muito judiado. Ele falava pra gente que ele sofreu muito, que ficava sem comer. Que ele apanhou muito. Ele casou - não sei a idade que ele casou -, mas esse tio que nasceu na semana da libertação é o tio mais velho da casa. O tio Joaquim brincava que graças a Deus ele era um negro feliz. Porque ele não pegou a escravidão. $E$ o vovô sempre falava pra ele que se ele pegasse a escravidão ele ia dar valor [...] Ele dizia que ele chegou a ser amarrado várias vezes. Uma vez ele contou pra nós que puseram ele naquele castigo do ralo. Você já ouviu falar no castigo do ralo? É uma roda que quando eles queriam castigar um escravo... mas tinha que ser uma causa justa... bom... não tinha causa justa, porque eles castigavam mesmo... Mas eles punham eles sentados naquele ralo e aquele ralo tinha cada prego. Eu cheguei a conhecer o ralo. Tinha vários pregos. Uma rodada só e a pessoa que sentava naquilo saia em sangue vivo. E ele chegou a ir para a roda da escravidão [...] Ele contava que foi muito doloroso, muita fome ele passou, muitas prisões. Ele fugiu duas vezes. Pegaram ele e foi pior depois, porque depois que pegavam o fugitivo apanhava dobrado. Mas depois alguém vendeu ele. Ele foi vendido quando a escravidão já ia acabando. Ele foi vendido junto com a família e tudo, quando ele já estava com a minha avó. Ele já estava casado com a minha avó, só que a minha avó não era da mesma fazenda dele. (Grifos nossos)

A partir dessas histórias dos tempos da escravidão, de Mariinha e de dona Tereza, pode-se falar em memórias do cativeiro, assim como concluiu a historiadora Hebe 
M. Mattos de Castro, em suas pesquisas no Vale do Paraíba (SP e RJ). A história-oral, construída a partir das histórias de vida dessas duas famílias, foi fundamental.

Nessas duas entrevistas, observa-se que o estreitamento dos laços familiares entre os entrevistados e seus interlocutores primários (seus parentes - avó e avô) permitiu a construção dessas memórias. Jorge Basílio, avô de Mariinha, e Pracide Maria José, bisavó de dona Tereza são exemplos de que na senzala existia cultura, tradições e noções de organização social e política.

Apesar de o escravismo estar calcado na humilhação e na desumanização de africans e afrobrasileiros, a ideologia dominante não conseguiu apagar as tradições, as identidades e as memórias trazidas de além-mar, que, em território brasileiro, enriqueceu a nossa cultura tradicional - seja na arte, na música, nos festejos (como, por exemplo, o Jongo), na culinária, no modo de vida, na visão de mundo, na cultura e na educação das gerações dessas famílias.

\section{As memórias do Jongo em Bananal}

A partir de agora trataremos das memórias do Jongo. A roda de Jongo é composta por homens e mulheres que formam um círculo. Tradicionalmente a composição ocorria próxima a uma fogueira, fundamental para a afinação do couro dos tambores: o maior deles chamado de bumbu/caxambu/tambor (dependendo da região no Vale do Paraíba) e o menor de candongueiro.

Em uma das entrevistas realizadas em Bananal, ficou explícita a figura do mestre jongueiro: aquele que coordena a roda e a afinação dos instrumentos. Os pontos são entoados pelo jongueiro ou jongueira, que vai ao centro da roda e qualquer um pode lançar seu ponto. O coro responde, repetindo o último verso do ponto. Mulheres e homens, além de cantar, dançam no meio da roda e nossos interlocutores afirmaram que isso ocorria sem nenhum contato entre eles. Rodopiando seus corpos, eles são levados pelo som dos tambores.

Os escravizados celebraram o fim do escravismo com muita música e dança, afirmou uma entrevistada. A avó de dona Tereza, Camila Maria, dançou muito Jongo nos terreiros das fazendas em Bananal. Recordando as histórias dessa avó sobre o dia da abolição, dona Tereza nos revelou: "Ih! Ela dizia que fizeram festa. Dizia que os fazendeiros disseram: Vocês podem fazer festa! Pode dançar. Dizem que eles só dançavam Jongo".

O Jongo foi um ritmo bastante popular entre os negros africanos e brasileiros no tempo da escravidão e se tornou comum nos festejos tradicionais, tanto entre eles quanto entre o restante da população não negra da cidade de Bananal. Há de se pontuar também que o ritmo foi ganhando novos adeptos ao longo do tempo, o que foi constatado numa conversa com outra interlocutora, de ascendência italiana, chamada Joana D 'arc Sabadine dos Santos, que dizia frequentar as rodas com sua família. O Jongo foi praticado em Bananal até 1970 e hoje ainda se mantém na memória de seus habitantes.

Ele é uma importante expressão da nossa cultura e foi estudado por alguns pesquisadores, tais como a folclorista Maria de Lourdes Borges Ribeiro (Lourdes Borges), Stein (1961), Lara \& Pacheco (2007), entre outros. Além de haver um conjunto de pesquisas sobre o Jongo, em novembro de 2005 essa manifestação foi elevada a patrimônio imaterial, após longo estudo do Centro Nacional do Folclore e Cultura Popular (CNFCP) do Instituto do Patrimônio Histórico e Artístico Nacional (IPHAN), que produziu o Dossiê IPHAN nº 5 (Brasil, 2007) no qual o Jongo no Sudeste está inventariado 6 .

Perguntamos como e onde se formavam as rodas de Jongo e dona Tereza respondeu: "Lá na casa dos meus pais. Tinha também uma família lá perto da fazenda Bom Retiro, que em toda véspera de São Pedro fazia festa e tinha Jongo. Todo o ano tinha. Os homens cantavam e as mulheres cantavam. Os homens cantavam e as mulheres respondiam".

Para Gilroy (2001) a antifonia no canto (o chamado e a resposta), característica do Jongo e descrita por dona Tereza no trecho acima, é a principal marca da tradição musical negra da diáspora. Para o autor, as performances musicais negras são experienciadas pela identidade de maneira intensa "e às vezes reproduzida por meio de estilos negligenciados de prática

6 Dossiê disponível para consulta na página (acesso em 02.09.2017): http://www.cnfcp.gov.br/pdf/Patrimonio_Imaterial/Dossie_Patrimonio_Imaterial/Dossie_Jongo.pdf 
significante como a mímica, gestos, expressão corporal e vestuários" (Gilroy, 2001, pp. 166-167).

O historiador americano Stein (1961) foi o primeiro a gravar pontos de Jongo na cidade de Vassouras, em 1949, Vale do Paraíba fluminense, no momento em que desenvolveu sua historiografia sobre a economia brasileira no século XIX, na obra Grandeza e Decadência do Café no Vale do Paraíba. Suas gravações estão hoje publicadas em Memória do Jongo de Lara \& Pacheco (2007).

Segundo os jongueiros locais, o som dos tambores é capaz de despertar níveis de consciência distintos naqueles que dançam. São inúmeros os relatos que deixam implícita a força mágica do som dos tambores, pois eles são considerados os elementos de conexão entre o plano material e o metafísico, segundo a cosmogonia negra (Slenes, 2007) ${ }^{7}$.

Observa-se pelas entrevistas, que eram inúmeras as famílias que organizavam suas rodas de Jongo e que a manifestação era algo recorrente. No trecho abaixo, nossa interlocutora canta um ponto:

Mais o Jongo era bonito. Quando era ali para a meia-noite, e a gente já estava com sono, escutava aquelas vozes daquelas mulheres cantando alto. Mas aquilo era muito bom. Os homens cantavam e elas respondiam, por exemplo:

Os homens diziam: "Cai sereno, cai"

Elas respondiam: "No cabelo de Maria" [risos]

E ficava aquilo. Quando estavam dançando era de dois casais só. Quando outra dama queria dançar, ela entrava e a outra dama saía. E os homens era a mesma coisa. Pulava lá e o outro saía, pra deixar o outro dançando.

Dona Tereza se lembrava de muitos detalhes e, em certo momento, acabou nos falando das roupas: "Eram tudo comprida. Quando girava aquelas saia

7 No Caderno de Campo está registrado um relato, comum entre os jongueiros em todo o Vale do Paraíba, segundo o qual, depois de encerrada a apresentação de Jongo, no lugar dos tambores abriam-se buracos no chão, tal era a animação da roda de Jongo. Em outros relatos a poeira do chão se levantava quase que magicamente. rodada, voava assim". A entrevistada, ao nos informar sobre a dança, trouxe à tona tanto memórias de sua avó, como algumas vivências de sua infância nas rodas de Jongo e são essas vivências que a faziam se recordar do segundo ponto:

[cantando]

Bate tambor grande,

Repilica o candongueiro,

Tambor grande é minha cama,

O pequeno é meu travesseiro

Em Bananal encontramos um cenário importante do Brasil oitocentista (tanto pela arquitetura, como pelos costumes e tradições) e fizemos dele nosso laboratório a céu aberto para o estudo da escola, da memória social e da cultura popular. Este foi o cenário perfeito para reviver a memória do Jongo e dos Jongueiros, através de cinco entrevistas realizadas.

As memórias do Jongo em Bananal são basicamente de três períodos diferentes: a) do período pós-abolição; b) do início do século XX; c) e quando o Jongo passou a ser praticado na Praça do Rosário, entre 1940 a 1970. De manifestação cultural proibida no século XIX, o Jongo se tornou reflexo das manifestações da cultura popular no momento em que deixou de ocorrer apenas nos terreiros das fazendas e passou a ser apresentado na praça central.

Dona Tereza assim se referiu ao período em que o Jongo ocorria na Praça do Rosário, onde, aliás, está localizado o Solar Manoel de Aguiar Vallim, um dos maiores escravocratas do período:

Conforme eles iam batendo no tambor, o pessoal dançava. As mulheres também dançavam com os homens. Mas dizem que a dança deles era assim. Ninguém punha a mão no outro. Eles dançavam um aqui e outro ali. Um ia pra lá e o outro vinha pra cá. Eu sei que eles dançavam a noite inteira. Eu não sou do tempo da escravidão, mas eu ainda cheguei a ver o Jongo. Porque tinha muita gente antiga. $A$ gente [os mais novos] já gostava do forró. Mas nóis no forró ouvia o Jongo e nóis achava bonito. 
O Jongo foi uma manifestação própria da senzala, praticada como uma forma de subterfúgio da vida no sistema escravocrata, mas foi, ao longo do século $X X$, ganhando novos espaços, cenários e adeptos. 0 Jongo se tornou referência de musicalidade na senzala, mas também na cultura popular no século $X X$, além de fazer um contraponto com os salões nobres de meados do século XIX.

O terreiro (o quintal da propriedade agroexportadora de café), espaço público que compartilhavam escravizados e senhores, foi sempre o intermédio entre o salão nobre e a senzala. No salão, como se pode afirmar pela obra de Castro \& Schnoor (1995), tocava-se ópera e dançava-se valsa. No terreiro tocava-se e dançava-se o Jongo no período do Brasil Imperial (1808 - 1889).

Em todos os 13 de maio ocorriam rodas de Jongo no Vale do Paraíba (Slenes, 2007). O ritmo, surgido nas senzalas, tornou-se código cultural antes do Samba. As rodas de Jongo eram realizadas em festas de casamento, festas juninas e para comemorar os dias dos santos católicos, como afirma dona Tereza.

Zezinho do Sancho, José Cândido de Santa Rosa, nascido em Bananal, no momento da entrevista (11 de abril de 2012) com 62 anos, mencionou como particularidades do Jongo a tradição oral e o modo astuto de se criticar o sistema social: "Ele é uma coisa quase igual a um código, que eu aprendi muito com minha tia e os antigos. Os negros queriam falar uma coisa para que os patrões não ficassem sabendo, cantavam o Jongo e cada palavra significava uma coisa".

Nesse trecho, Zezinho do Sancho confirma as hipóteses de Gilroy (2001), que afirma ter a música na diáspora adquirido traços de uma cultura de resistência ou de contracultura. Segundo o autor, subjugados à dinâmica escravista, "a música se torna vital no momento em que a indeterminação/polifonia linguística e semântica surgem em meio à prolongada batalha entre senhores e escravos" (Gilroy, 2001, p. 160).

É comum os pontos serem interpretados pelos jongueiros. Além disso, encontramos variações de um mesmo ponto em diferentes cidades do Vale do Rio Pa- raíba do $\mathrm{Sul}^{8}$, como é o caso do ponto a seguir, cantado por Zizinho, por José Maria Nogueira (com 65 anos no momento da entrevista e que muito nos falou do mestre-jongueiro Sebastião Rosa, seu pai) e por sua mãe, também jongueira: Sebastiana Nogueira Rosa:

[cantando]

No meio de tanto pau,

Embaúba é coronel,

[Damas:] Embaúba é coronel?.

Zizinho foi quem nos explicou que todo ponto pode ser desatado. Isso significa que quando desveladas as entrelinhas de um ponto, se consegue perceber qual é a crítica ou revelação que o verso contém a respeito da realidade cotidiana. No ponto acima, temos uma crítica social. A embaúba, na realidade, representaria a figura do coronel, mas que não passa de um ser humano comum, como a árvore em questão é comum no bioma da mata Atlântica.

Zezinho do Sancho foi quem nos desatou o ponto a seguir: "O tatu tá de cangaia/ Coro: mantimento de quem é?/ mantimento de quem é?”. Disse-nos Zizinho (em entrevista no dia 02 de maio de 2012) que o tatu representaria uma mulher grávida, cuja comunidade desconheceria o pai da criança. O ponto, portanto, descortina as dinâmicas sociais ou costumes.

Zizinho e Zezinho deixam evidente que os pontos são matreiros e carregados de "significados argutos e humor astucioso (...) [de gente que aprendeu] a arte do subterfúgio e da ironia como um meio termo entre a submissão e a revolta" (Slenes, 2007, p. 112). Algo que também havia sido percebido por Stein (1961). Novamente, temos o Jongo também revelando entrelinhas de relações de poder.

8 Segundo Lara \& Pacheco (2007), foi Lourdes Borges a primeira a coletar uma variação desse verso de Jongo no Vale do Paraíba paulista, no município de Cunha.

9 A Embaúba é uma árvore bastante comum na região de mata Atlântica. Por ser uma espécie pouco exigente quanto ao solo, é possível encontrá-la mesmo em áreas de pouca preservação ambiental. Aliás, a abundância dessa espécie indica a pouca preservação, já que prolifera após desmatamentos. 


\section{Referências}

Alencastro, L. F. (2000) O Trato dos Viventes: a formação do Brasil no Atlântico Sul. São Paulo: Companhia das Letras.

Castro, H. M. M. \& Schnoor, E. (org) (1995) Resgate: uma janela para o oitocentos. Rio de Janeiro: Topbooks.

Gilroy, P. (2001) O Atlântico Negro: modernidade e dupla consciência. São Paulo: Editora 34; Rio de Janeiro: Universidade Candido Mendes, Centro de Estudos Afro-Asiáticos.

Graça, P. (org.) (2006) Estância Turística e Ecológica de Bananal: Terra dos Barões do Café. São Paulo: Noovha América.

Knight, F. W. (2011) A Diáspora Africana. In: Ade Ajayi, J. F. (editor) África do Século XIX à Década de 1880. São Paulo: Cortez; Brasília: UNESCO (vol. VI - Coleção História Geral da África).

Lara, S.H. \& Pacheco, G. (org.) (2007) Memória do Jongo: As gravações históricas de Stanley Stein, Vassouras, 1949. Rio de Janeiro: Folha Seca.

Motta, J. F. (1999) Corpos Escravos, Vontades Livres: posse de cativos e família escrava em Bananal (1801-1829). São Paulo: FAPESP: AnnaBlume.

Slenes, R. (2007) Eu venho de muito longe, eu venho cavando: jongueiros cumba na senzala centro-africana. In: Lara, S.H. \& Pacheco, G. (org.) Memória do Jongo: As gravações históricas de Stanley Stein, Vassouras, 1949. Rio de Janeiro: Folha Seca.

Stein, S. J. (1961) Grandeza e Decadência do Café no Vale do Paraíba. São Paulo: Brasiliense.

Vansina, J. (2011) O Reino do Congo e seus vizinhos. In: Ogot, B.A. (editor) África do século XVI ao XVIII. São Paulo: Cortez; Brasília: UNESCO (vol. V - Coleção História Geral da África).

Vitorino, D. C. (2014) Um Divórcio entre a Escola e a Comunidade? Bananal/SP um "laboratório" a céu aberto no Vale Histórico do Rio Paraíba do Sul. Araraquara - SP. Tese de Doutorado: FCL-Ar/UNESP. 